\title{
Pengukuran Kualitas Website Point of Sales System Divisi Bisnis UMM Menggunakan Metric Function Oriented
}

\author{
Adam Pamungkas Ramadhan *1, llyas Nuryasin ${ }^{2}$, Wildan Suharso ${ }^{3}$ \\ 1,2,3Teknik Informatika/Universitas Muhammadiyah Malang \\ officialapr19@gmail.com*
}

\begin{abstract}
Abstrak
Metric Function Oriented merupakan metrik yang menggunakan ukuran fungsionalitas dari suatu aplikasi atau sistem sebagai nilai normalisasi. Dalam hal ini, fungsionalitas dapat diukur secara tidak langsung dengan menggunakan metode Function Point. Function Point ini diturunkan menggunakan hubungan dari pengamatan yang dilakukan berdasarkan ukuran domain informasi perangkat lunak secara langsung yang dapat dihitung dan penilaian perangkat lunak dari sisi kompleksitasnya. Hasil yang didapatkan pada pengumpulan data berupa fungsionalitas dan spesifikasi dari suatu sistem. Untuk perhitungan Unadjusted Function Point, Value Adjustment Factor, dan Function Point hasil yang didapat masing-masing memiliki nilai 247, 0.92, dan 227.24. Sedangkan untuk hasil evaluasi indikator kegagalan berupa nilai kualitas yang dimiliki yaitu 95\% yang mana nilai tersebut merupakan nilai kualitas dari website point of sales system milik Divisi Bisnis UMM.
\end{abstract}

Kata Kunci: Metric Function Oriented, Unadjusted Function Point, Value Adjustment Factor, Function Point, Evaluasi Indikator Kegagalan

\begin{abstract}
Metric Function Oriented is a metric that uses a measure of functionality of an application or system as a normalized value. In this case, functionality can be measured indirectly by using the Function Point method. This function point is derived using the relationship of observations made based on the size of the domain of software information that can be directly calculated and the software's assessment in terms of its complexity. The results obtained in the collection of data in the form of functionality and specifications of a system. For the calculation of the Unadjusted Function Point, Value Adjustment Factor, and Function Point the results obtained are 247, 0.92, and 227.24, respectively. As for the results of the evaluation of the failure indicator in the form of quality value that is $95 \%$ which is the value of quality from the point of sales system website of the UMM Business Division.
\end{abstract}

Keywords: Metric Function Oriented, Unadjusted Function Point, Value Adjustment Factor, Function Point, Evaluation of the Failure Indicator

\section{Pendahuluan}

Teknologi dan informasi saat ini telah menjadi sebuah kebutuhan yang bermanfaat untuk setiap pengguna di masyarakat baik secara individu, pelaku bisnis, instansi pemerintahan maupun lembaga pendidikan. Hal-hal tersebut yang menjadi penyebab teknologi dan informasi berkembang sangat pesat terutama di dunia bisnis lembaga pendidikan seperti universitas khususnya pada Divisi Bisnis UMM.

Divisi Bisnis UMM merupakan Unit Bisnis dari Lembaga Infokom UMM yang menyediakan layanan untuk keperluan Mahasiswa/wi di Universitas Muhammadiyah Malang diantaranya Billing Internet (Warnet), Print dan Scan Document, Burning Disc, Service Printer dan Laptop, Jual Beli Makanan (Snack) dan Minuman. Dalam melakukan transaksi jual beli makanan yang dilakukan hampir setiap harinya, Divisi Bisnis UMM memiliki serta menggunakan sebuah website point of sales system demi membantu serta memudahkan proses transaksional.

Berkembangnya standar kualitas yang semakin banyak saat ini menjadi bukti bahwa pencapaian sebuah kualitas sangat penting. Pentingnya sebuah kualitas dari suatu aplikasi atau website masih dihadapkan dengan banyaknya standar kualitas yang ada [1].

Pencapaian kualitas sebuah aplikasi atau website dinilai dengan melakukan pengukuran. Pengukuran perangkat lunak merupakan hal yang paling penting dari praktek rekayasa perangkat 
lunak yang baik dan benar. Tidak hanya itu saja, pengukuran melalui aktivitas manusia menambah nilai dan terlibat aktif dalam proses informasi. Pengukuran ini membantu untuk membuat karakteristik khusus dari proses dan produk informasi.

Pengukuran merupakan kegiatan untuk menghitung nilai kuantitatif dari luasan, dimensi, kapasitas, atau atribut sebuah produk. Terdapat dua cara untuk melakukan pengukuran yaitu pengukuran langsung dan tidak langsung. Pengukuran langsung adalah pengukuran mengenai biaya dan usaha yang dibutuhkan untuk sebuah aplikasi atau website. Sedangkan pengukuran tidak langsung contohnya adalah pengukuran kualitas. Terdapat berbagai atribut perangkat lunak yang diukur, untuk pengukuran tidak langsung atribut yang dipakai adalah efisiensi, reliabilitas, kemampuan pemeliharaan, dan fungsionalitas. Dalam kasus ini peneliti ingin mengangkat sebuah penelitian yang mengukur nilai kualitas dari suatu aplikasi atau website menggunakan atribut atau ukuran dari segi fungsionalitasnya yang salah satunya menggunakan metode Metric Function Oriented.

Metric Function Oriented merupakan metrik yang menggunakan ukuran fungsionalitas dari suatu aplikasi atau sistem sebagai nilai normalisasi. Dalam hal ini, fungsionalitas dapat diukur secara tidak langsung dengan menggunakan metode Function Point. Function Point ini diturunkan menggunakan hubungan dari pengamatan yang dilakukan berdasarkan ukuran domain informasi perangkat lunak secara langsung yang dapat dihitung dan penilaian perangkat lunak dari sisi kompleksitasnya.

Beberapa penelitian yang serupa seperti pada penelitian [1][2][3][4][5] merupakan penelitian tentang pengukuran kualitas pada perangkat lunak menggunakan Metric Function Oriented. Perangkat lunak yang diukur dalam studi kasus penelitian [1][2][3][4] yaitu aplikasi $e$ learning dan sistem manajemen pelaporan kegiatan. Sedangkan pada penelitian [5] hanya memberikan penjelasan terhadap model pengukuran kualitas perangkat lunak yang dikembangkan menggunakan metode Function Point.

Hal yang mendasari dan menguatkan bahwa munculnya penelitian ini yaitu belum pernah dilakukan pengukuran kualitas terhadap Divisi Bisnis UMM khususnya pada website point of sales system. Tidak hanya itu saja, Kepala Divisi Bisnis UMM juga ingin mengetahui seberapa besar nilai kualitas website point of sales system untuk dijadikan dokumentasi akhir yang dapat dipakai untuk kedepannya dalam menentukan keputusan-keputusan yang dibuat. Oleh karena hal tersebut, maka peneliti melakukan pengukuran kualitas website point of sales system pada Divisi Bisnis UMM dengan menggunakan Metric Function Oriented.

\section{Metode Penelitian}

Metode pada Gambar 1 yang digunakan dalam penelitian ini terdiri dari beberapa tahapan yaitu dimulai dari tahapan Identifikasi Masalah, Studi Literatur, Pengumpulan Data, perhitungan Unadjusted Function Point, perhitungan Value Adjustment Factor, perhitungan Function Point, dan Evaluasi Indikator Kegagalan.

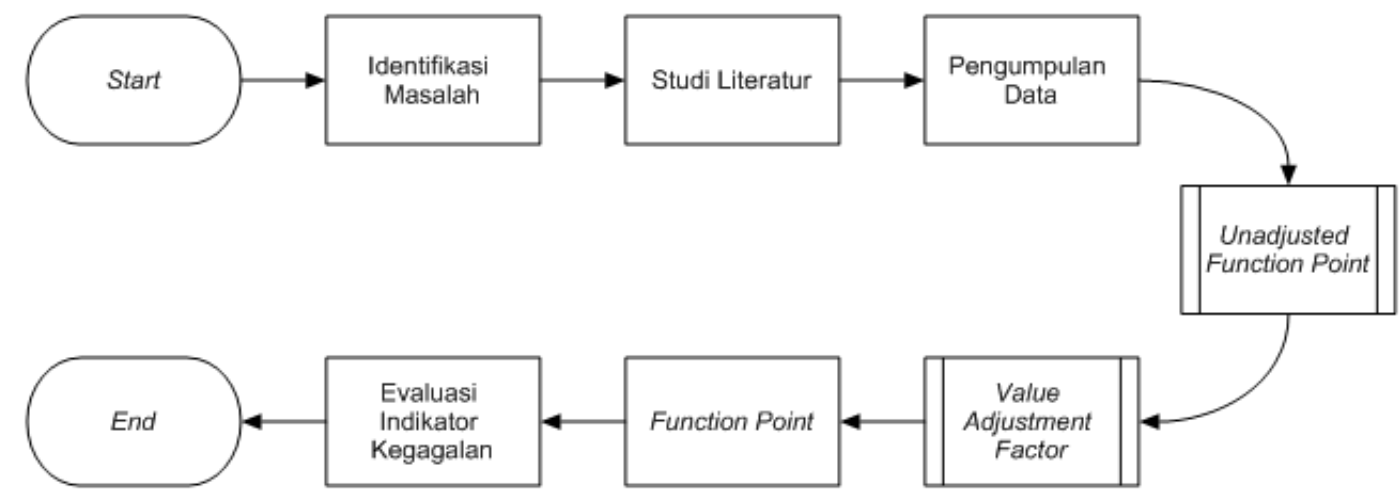

Gambar 1. Flowchart Metode Penelitian

\subsection{Identifikasi Masalah}

Tahapan awal dilakukan identifikasi permasalahan yang ada terhadap stakeholder khususnya pada website Point of Sales System milik Divisi Bisnis UMM yang kemudian akan menghasilkan sebuah rumusan-rumusan masalah. 


\subsection{Studi Literatur}

Pada tahap ini dilakukan pembelajaran dari sumber-sumber referensi [6][7][8][9], [10][11][12][13][14] (e-book, jurnal, artikel, dll) yang berkaitan dengan Rekayasa Perangkat Lunak khususnya pada topik penelitian tentang pengukuran kualitas dan metode Metric Function Oriented.

\subsection{Pengumpulan Data}

Pada tahap ini peneliti melakukan pengamatan / observasi kepada pihak terkait. Data yang diperoleh peneliti merupakan hasil pengamatan / observasi terhadap website Point of Sales System milik Divisi Bisnis UMM.

\subsection{Perhitungan Unadjusted Function Point}

Langkah-langkah untuk menghitung Unadjusted Function Point :

1. Menentukan nilai dari hasil pengumpulan data pada masing-masing komponen antara lain External Input, External Output, External Inquiries, Internal Logical Files, dan External Interface Files.

2. Pemberian bobot kompleksitas pada masing-masing komponen berdasarkan kompleksitas fungsinya.

3. Mendapatkan nilai Unadjusted Function Point dari hasil total jumlah perhitungan penjumlahan serta multiplikasi nilai dari masing-masing komponen dan bobot kompleksitasnya.

\subsection{Perhitungan Value Adjustment Factor}

Tabel 1 menunjukkan Value Adjustment Factor didasarkan pada 14 Karakteristik Sistem Umum yang menilai fungsionalitas umum aplikasi yang sedang dihitung. Setiap karakteristik memiliki deskripsi yang terkait untuk menentukan tingkat pengaruh.

Tabel 1. Karakteristik Sistem Umum

\begin{tabular}{|c|c|c|}
\hline \multicolumn{2}{|r|}{ Karakteristik Sistem } & Keterangan \\
\hline 1. & Komunikasi Data & Perlukah komunikasi data? \\
\hline 2. & Pemrosesan Data Secara & Adakah fungsi pemrosesan terdistribusi? \\
\hline 3. & Performa & Pentingkah suatu performansi? \\
\hline 4. & $\begin{array}{l}\text { Konfigurasi Yang Banyak } \\
\text { Diqunakan }\end{array}$ & Semua komponen kompleks? \\
\hline $\begin{array}{l}5 . \\
6 .\end{array}$ & $\begin{array}{l}\text { Tingkat Transaksi } \\
\text { Entri Data Secara Online }\end{array}$ & $\begin{array}{l}\text { Haruskah transaksi input dibangun? } \\
\text { Perlukah entri data secara online terhadap sistem? }\end{array}$ \\
\hline 7. & Efisiensi Pengguna Akhir & $\begin{array}{l}\text { Apakah sistem memerlukan cadangan dan pemulihan } \\
\text { yang andal? }\end{array}$ \\
\hline 8. & $\begin{array}{l}\text { Pembaharuan Secara } \\
\text { Online }\end{array}$ & Perbaharuan file master secara online? \\
\hline 9. & $\begin{array}{l}\text { Pemrosesan Yang } \\
\text { Kompleks }\end{array}$ & Komplekskah pemrosesan secara internal? \\
\hline 10. & Dapat Digunakan Kembali & Sintaks atau kode dirancang untuk reusability? \\
\hline 11. & $\begin{array}{l}\text { Kemudahan Dalam } \\
\text { Instalasi }\end{array}$ & Suatu konversi dan pemasangan pada bagian desain? \\
\hline 12. & $\begin{array}{l}\text { Kemudahan Dalam } \\
\text { Operasional }\end{array}$ & $\begin{array}{l}\text { Manfaatkah sistem berjalan dalam lingkungan operasional } \\
\text { yang tersedia? }\end{array}$ \\
\hline 13. & Beberapa Organisasi & $\begin{array}{l}\text { Perancangan suatu sistem digunakan pada banyak } \\
\text { organisasi? }\end{array}$ \\
\hline 14. & Mem & $\begin{array}{l}\text { Perancangan aplikasi meyediakan suatu perubahan serta } \\
\text { kemudahan pemakaian oleh pengguna? }\end{array}$ \\
\hline
\end{tabular}

Tingkat pengaruh berkisar pada skala 0 sampai 5 , dari tidak berpengaruh hingga berpengaruh kuat. Setiap karakteristik diberikan peringkat berdasarkan uraian detail yang mana adalah sebagai berikut :

0 Tidak ada, atau tidak ada pengaruh

1 Pengaruh sedikit

2 Pengaruh sedang 
3 Pengaruh rata-rata

4 Pengaruh signifikan

5 Pengaruh kuat di keseluruhan

Setelah semua 14 karakteristik umum sistem telah dijawab, kemudian ditabulasikan menggunakan Persamaan 1 sebagai berikut.

$$
\mathrm{VAF}=0.65+\left[\left(\sum_{\mathrm{i}=1}^{14} \mathrm{Ci}\right) / 100\right]
$$

\subsection{Perhitungan Function Point}

Untuk menghitung Function Point menggunakan rumus standar pada Persamaan 2 sebagai berikut.

$$
F P=U A F \times V A F
$$

\subsection{Evaluasi Indikator Kegagalan}

Setelah mendapatkan nilai FP, maka dapat digunakan sebagai acuan untuk mengukur kualitas perangkat lunak dengan cara membandingkan nilai FP dengan banyak error (kegagalan) yang terdapat pada perangkat lunak tersebut khususnya pada Website Point of Sales System Divisi Bisnis UMM, yang mana Persamaan 3 seperti berikut.

$$
\text { Kualitas }=100 \%-(\text { Kesalahan } / \mathrm{FP} \times 100 \%)
$$

\section{Hasil Penelitian dan Pembahasan}

Pada bab ini diperoleh hasil pada penelitian berupa pengumpulan data, perhitungan Unadjusted Function Point, perhitungan Value Adjustment Factor, perhitungan Function Point, dan evaluasi indikator kegagalan.

\subsection{Pengumpulan Data}

\begin{tabular}{|c|c|c|}
\hline Nama Data & Item & Jumlah \\
\hline Inputan Pengguna & $\begin{array}{c}\text { Input Link ke Form Login } \\
\text { Input Username \& Password } \\
\text { Input Item Baru } \\
\text { Input Pencarian } \\
\text { Input Item Receiving } \\
\text { Input Kuantitas (Receiving) } \\
\text { Input Penjualan } \\
\text { Input Kuantitas (Penjualan) }\end{array}$ & 8 \\
\hline Output Pengguna & $\begin{array}{c}\text { Form Login } \\
\text { Pop Up Absen } \\
\text { Pop Up Absen Pulang } \\
\text { Daftar Produk / Item } \\
\text { Form Item Baru } \\
\text { Output Pre-Item Receiving } \\
\text { Output Item Receiving } \\
\text { Output Pre-Penjualan } \\
\text { Output Penjualan } \\
\text { Rekap Absensi Per-hari } \\
\text { Rekap Absensi Per-orang } \\
\text { Laporan Penjualan }\end{array}$ & 12 \\
\hline $\begin{array}{c}\text { Permintaan } \\
\text { Pengguna }\end{array}$ & $\begin{array}{l}\text { Tombol Login } \\
\text { Menu Beranda }\end{array}$ & 31 \\
\hline
\end{tabular}

Pada Tabel 2, data yang diperoleh peneliti didapatkan dari hasil pengamatan atau observasi terhadap website Point of Sales System milik Divisi Bisnis UMM.

Tabel 2. Hasil Pengumpulan Data

REPOSITOR, Vol. 2, No. 7, Juli 2020: 881-888 
Tombol Absen Pulang

Menu Produk / Item

Tombol Item Baru

Tombol Kirim (Item Baru)

Sorting Item

Tombol Hapus (Produk / Item)

Tombol Ubah Massal (Produk / Item)

Tombol Hasilkan Barcode (Produk /

Item)

Tombol Ubah (Item)

Tombol Inventaris (Item)

Tombol Details (Item)

Menu Laporan

Tombol Graphical Reports

Tombol Summary Reports

Tombol Detailed Reports

Tombol Inventory Reports Menu Receivings

Tombol Hapus (Receiving)

Tombol Cancel (Receiving)

Tombol Finish (Receiving) Menu Penjualan

Tombol Hapus (Penjualan)

Tombol Add Payment

Tombol Entri Penjualan Menu Absensi

Tombol Absensi Per-hari

Tombol Absensi Per-orang

Menu Laporan Harian Tombol Penjualan

File Absensi

File Konfigurasi

File Pelanggan

File Pegawai

File Inventory

File

File Item

File Receiving

File Receiving Items

File Penjualan

File Item Penjualan

File Pembayaran Penjualan

\begin{tabular}{|c|c|c|}
\hline Interface Eksternal & $T C P / I P$ & 1 \\
\hline $\begin{array}{c}\text { Bahasa } \\
\text { Pemrograman }\end{array}$ & PHP & 1 \\
\hline Basis Data & MySQL & 1 \\
\hline Web Server & XAMPP & 1 \\
\hline Sistem Operasi & Windows & 1 \\
\hline Kegagalan (Error) & $\begin{array}{c}\text { - Tidak bisa menghasilkan suatu } \\
\text { barcode pada produk / item } \\
\text { - Terkadang slow respons dalam } \\
\text { melakukan inputan penjualan } \\
\text { - Setelah itu, di-refresh kembali } \\
\text { kemudian menampilkan inputan } \\
\text { penjualan ganda } \\
\text { - Setelah melakukan add payment \& } \\
\text { entri penjualan, terdapat pesan } \\
\text { Sales Transaction Failed } \\
\text { - Terkadang logout sendiri }\end{array}$ & 11 \\
\hline
\end{tabular}

Pengukuran Kualitas Website Point of Sales... 
- Tidak dapat menambahkan item

$$
\text { baru }
$$

- Beberapa item tidak dapat diubah

(modif)

- Tidak dapat menampilkan

Graphical Reports

- Tidak dapat menampilkan

Summary Reports

- Tidak dapat menampilkan Detailed

$$
\text { Reports }
$$

- Tidak dapat menampilkan

Inventory Reports

\subsection{Perhitungan UAF (Unadjusted Function Point)}

Perhitungan Unadjusted Function Point didasarkan pada Gambar 2 yang tertera pada Tabel 3 berikut.

Tabel 3. Hasil Perhitungan Unadjusted Function Point

\begin{tabular}{lcccccc}
\hline \multirow{2}{*}{ Jenis Komponen } & \multirow{2}{*}{ Jumlah } & \multicolumn{5}{c}{ Faktor Pembobotan } \\
\cline { 3 - 7 } & & $\times$ & Sederhana & Rata-Rata & Tinggi & Total \\
\hline External Input & 8 & $\times$ & 3 & 4 & 6 & 24 \\
External Output & 12 & $\times$ & 4 & 5 & 7 & 48 \\
External Inquiries & 31 & $\times$ & 3 & 4 & 6 & 93 \\
Internal Logical Files & 11 & $\times$ & 7 & 10 & 15 & 77 \\
External Interface Files & 1 & $\times$ & 5 & 7 & 10 & 5 \\
\hline & & & Unadjusted Funnction Point & 247 \\
\hline
\end{tabular}

Unadjusted Function Point

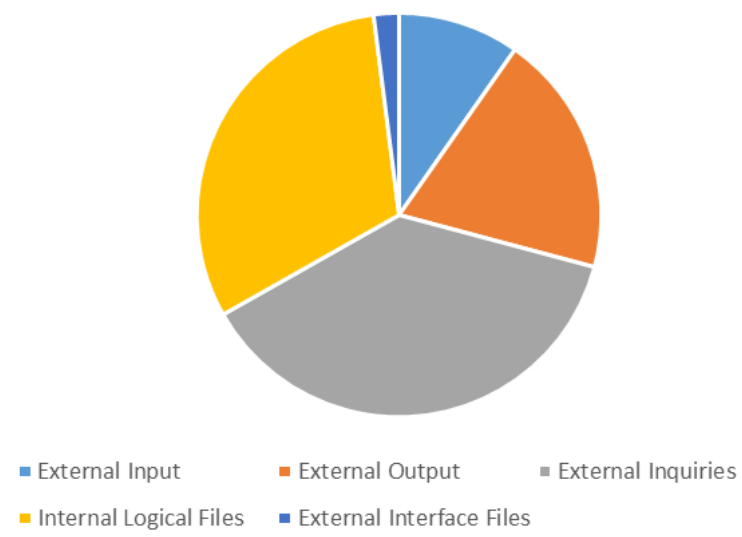

Gambar 2. Pemodelan Unadjusted Function Point

\subsection{Perhitungan VAF (Value Adjustment Factor)}

Penilaian karakteristik sistem didasarkan pada Tabel 1 sedangkan untuk penilaian masingmasing karakteristik sistem didasarkan pada Tabel 4 dan Gambar 3.

Tabel 4. Penilaian Karakteristik Sistem Umum

\begin{tabular}{llc}
\hline & \multicolumn{1}{c}{ Karakteristik Sistem } & Penilaian \\
\hline 1. & Komunikasi Data & 4 \\
2. & Pemrosesan Data Secara Terdistribusi & 1 \\
3. & Performa & 2 \\
4. & Konfigurasi Yang Banyak Digunakan & 0 \\
5. & Tingkat Transaksi & 5 \\
6. & Entri Data Secara Online & 3 \\
\hline
\end{tabular}

REPOSITOR, Vol. 2, No. 7, Juli 2020: 881-888 
7. Efisiensi Pengguna Akhir 2

8. Pembaharuan Secara Online 3

9. Pemrosesan Yang Kompleks 1

10. Dapat Digunakan Kembali 1

11. Kemudahan Dalam Instalasi 1

12. Kemudahan Dalam Operasional 1

13. Beberapa Situs 1

14. Memudahkan Perubahan 2

Total 27

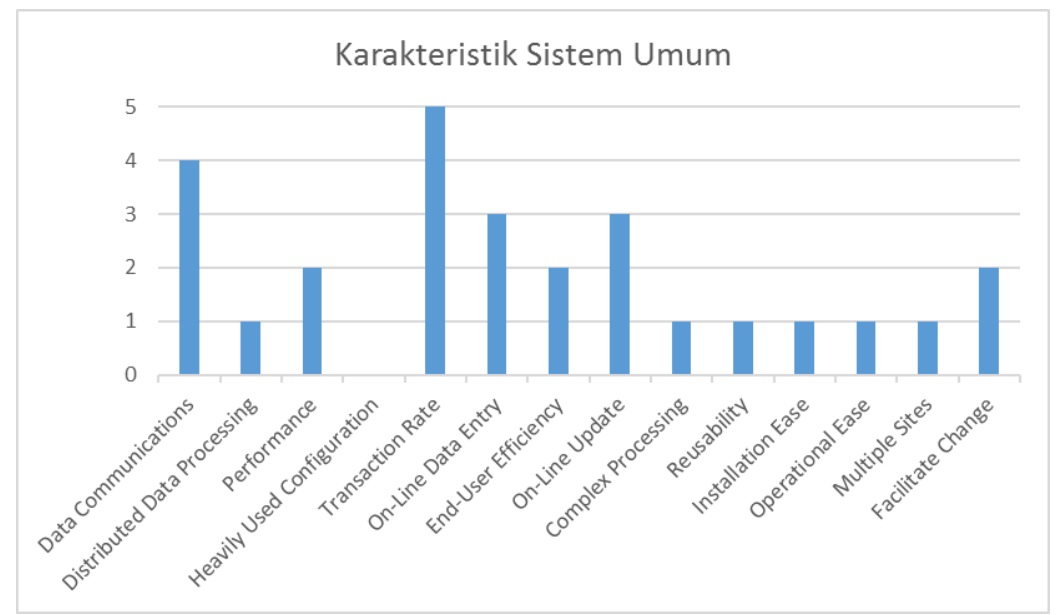

Gambar 3. Pemodelan Nilai Karakteristik Sistem Umum

Setelah semua 14 karakteristik umum sistem telah diidentifikasi, kemudian ditabulasikan menggunakan Persamaan 2 untuk menghitung nilai dari Value Adjustment Factor.

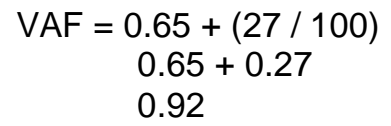

\subsection{Perhitungan FP (Function Point)}

Nilai UAF dan VAF sudah diketahui kemudian menghitung Function Point dengan rumus standar pada Persamaan 3 atau rumus secara rinci pada Persamaan 1.

$$
\begin{gathered}
\mathrm{FP}=\mathrm{UAF} \times \mathrm{VAF} \\
247 \times 0.92 \\
227.24
\end{gathered}
$$

\subsection{Evaluasi Indikator Kegagalan}

Setelah mendapatkan nilai dari Function Point kemudian nilai tersebut dimasukkan pada Persamaan 4 untuk mencari nilai kualitas.

$$
\begin{gathered}
\text { Kualitas }=100 \%-(\text { Kesalahan } / \mathrm{FP} \times 100 \%) \\
100 \%-(11 / 227.24 \times 100 \%) \\
100 \%-4.84 \% \\
95 \%
\end{gathered}
$$

\section{Kesimpulan}

Pengukuran kualitas yang dilakukan pada website point of sales system milik Divisi Bisnis UMM dengan menggunakan Metric Function Oriented memiliki beberapa tahapan metodologi, dimulai dari tahapan identifikasi masalah, studi literatur, pengumpulan data, perhitungan Unadjusted Function Point, perhitungan Value Adjustment Factor, perhitungan Function Point, dan evaluasi indikator kegagalan. 
Metric Function Oriented merupakan metrik yang menggunakan ukuran fungsionalitas dari suatu aplikasi atau sistem sebagai nilai normalisasi. Dalam hal ini, fungsionalitas dapat diukur secara tidak langsung dengan menggunakan metode Function Point. Function Point ini diturunkan menggunakan hubungan dari pengamatan yang dilakukan berdasarkan ukuran domain informasi perangkat lunak secara langsung yang dapat dihitung dan penilaian perangkat lunak dari sisi kompleksitasnya.

Hasil yang didapatkan pada pengumpulan data berupa fungsionalitas dan spesifikasi dari suatu sistem. Untuk perhitungan Unadjusted Function Point, Value Adjustment Factor, dan Function Point hasil yang didapat masing-masing memiliki nilai 247, 0.92, dan 227.24. Sedangkan untuk hasil evaluasi indikator kegagalan berupa nilai kualitas yang dimiliki yaitu $95 \%$ yang mana nilai tersebut merupakan nilai kualitas dari website point of sales system milik Divisi Bisnis UMM. Peneliti dapat memberikan saran atau rekomendasi antara lain :

1. Perlu dilakukan pengukuran perangkat lunak dengan menggunakan metode selain Metric Function Oriented.

2. Perlu melakukan penilaian kualitas dengan menggunakan metode selain evaluasi indikator kegagalan.

3. Perlu adanya perbaikan atau pembenahan terhadap 11 kegagalan yang ditemukan selama melakukan pengumpulan data.

\section{Daftar Notasi}

UAF : Nilai Unadjusted Function Point

VAF : Nilai Value Adjustment Factor

FP : Nilai Function Point

$\mathrm{Ci} \quad$ : Tingkat pengaruh untuk setiap karakteristik sistem umum

i $\quad$ : Dari 1 hingga 14 mewakili masing-masing karakteristik sistem umum

$\Sigma \quad$ : Penjumlahan dari semua 14 karakteristik sistem umum

\section{Referensi}

[1] R. - and M. Subchan, "Pengukuran Kualitas Perangkat Lunak Sistem Manajemen Pelaporan Kegiatan Berbasis Web Peringatan Berbasis Email," vol. 2, no. 2502, 2017.

[2] R. -, A. Goeritno, and E. Hadi, "Pengukuran Kualitas Perangkat Lunak Sistem E-Learning Menggunakan Metric Function Oriented," 2017, pp. 769-776.

[3] F. R. Hariri et al., "Pengukuran Kompleksitas Sistem E-Learning di UIN Maulana Malik Ibrahim Malang Menggunakan Metrik Function Oriented," pp. 245-250, 2019.

[4] R. K. Hapsari and M. J. Husen, "Estimasi Kualitas Perangkat Lunak Berdasarkan Pengukuran Kompleksitas Menggunakan Metrik Function Oriented," Semin. Nas. Sains dan Teknol. Terap. III, pp. 425-434, 2015.

[5] F. -, "Pengukuran Kualitas Perangkat Lunak Berdasarkan Kompleksitas Menggunakan Metode Function Point," J. Sist. Inf., vol. 1, no. 2, pp. 79-87, 2009.

[6] D. Galin, Software quality assurance: from theory to implementation. 2004.

[7] H. Kim and L. S. Niehm, "The Impact of Website Quality on Information Quality, Value, and Loyalty Intentions in Apparel Retailing," J. Interact. Mark., vol. 23, no. 3, pp. 221-233, 2009.

[8] P. S. Hasugian, "Perancangan Website Sebagai Media Promosi Dan Informasi," J. Inform. Pelita Nusant., vol. 3, no. 1, pp. 82-86, 2018.

[9] H. Nurmi, "Membangun Website Sistem Informasi Dinas Pariwisata," J. Edik Inform., vol. 1, no. 2, pp. 1-6, 2014.

[10] T. G. Yuarita and F. Marisa, "Perancangan Aplikasi Point of Sales (POS) Berbasis Web Menggunakan Metode Siklus Hidup Pengembangan Sistem," J. Teknol. dan Manaj. Inform., vol. 3, no. 2, pp. 167-171, 2017.

[11] A. S. Sani, F. Pradana, and D. S. Rusdianto, "Pembangunan Sistem Informasi Point Of Sales Terintegrasi Dalam Lingkup Rumah Makan Beserta Cabangnya (Studi Kasus: RM. Pecel Pincuk Bu Tinuk)," J. Pengemb. Teknol. Inf. dan IImu Komput. Univ. Brawijaya, vol. 2, no. 10, pp. 3249-3257, 2018.

[12] R. S. Pressman, Software Engineering - A Practitioner's Approach, Fifth. 2005.

[13] D. Longstreet, "Fundamentals \& Introduction of Function Point Analysis," SoftwareMetrics, 2005.

[14] D. Longstreet, "Function Points Analysis Training Course," Longstreet Consult. Inc. Acessed, vol. 2, p. 15, 2005. 